\title{
HERMENEUTIKA SONGKET SEBAGAI PAKAIAN ADAT DALAM PERSPEKTIF BUDAYA MINANGKABAU
}

\author{
Budiwirman $^{1 *}$, Syafwandi $^{2 *}$ \\ Program Studi Pendidikan Seni Rupa Jurusan Seni Rupa Fakultas Bahasa dan Seni \\ Universitas Negeri Padang \\ Jl. Prof. Dr. Hamta, Air Tawar Padang, Kel. Air Tawar Barat, Kec. Padang Utara, Kota Padang, Kode Pos 25171 \\ Sumatera Barat. Indonesia \\ Email: budiwirman1959@gmail.com/budi.wirman@yahoo.com
}

\begin{abstract}
Abstrak
Penelitian ini bertujuan untuk menafsirkan keberadaan songket dan hubungannya terhadap perilaku atau budaya masyarakat adat di Minangkabau, Setiap simbol yang terdapat pada songket dapat diterjemahkan sebagai pedoman hidup dalam bermasyarakat di Minangkabau, Oleh karena itu, metode penelitian yang digunakan adalah metode kualitatif, karena objek yang akan diteliti adalah kain songket Minangkabau sebagai ciptaan manusia dan dapat dijadikan sebagai simbol pencitraan diri dari si pemakainya. Jelaslah ia mengandung unsur-unsur nilai, norma dan simbol yang sulit dipertemukan dengan faktor angka, statistik dan quantum lainnya. Nilai, norma, dan simbol hanya mungkin dipertemukan dengan gejala-gejala alami (fenomenologis), interaksi simbolik dan budaya atau dengan analisis model interaktif. Model analisis ini memiliki tiga macam komponen analisis utama, yaitu reduksi data, sajian data dan penarikan kesimpulan/verifikasi yang saling terjalin pada saat sebelumnya, selama dan sesudah pengumpulan data. Peneliti bergerak di antara empat "sumbu" kumparan tersebut dan berlansung terus sampai data/informasi yang terkumpul dianggap memadai guna menjawab permasalahan penelitian dan penarikan kesimpulan. Dengan demikian, penelitian ini didasari oleh analisa dengan pendekatan hermeneutika, kain tenun songket menjadi bagian utama dalam perangkat pakaian para pemangku adat dalam sistim kekerabatan masyarakat adat Minangkabau, keberadaan kain tenun songket tersebut mendapat tempat yang istimewa, selain memiliki bentuk yang indah berkilauan benang emas, kain tenun songket juga dihiasi dengan bermacam motif hias yang diambil dari bentuk tumbuh-tumbuhan dan binatang yang terdapat di sekitar lingkungan alamnya. Kain tenun songket sebagai pakaian adat di Minangkabau pada prinsipnya bagian yang tidak dapat dipisahkan dari eksistensi seorang pemangku adat, khususnya Penghulu dan Bundo Kanduang. Pakaian yang dilengkapi dengan tenun songket itu dalam pendekatan kajian hermeneutika merupakan simbol yang dapat diterjemahkan menjadi nilai-nilai simbolik yang bermakna bagi tata kehidupan dan suri tauladan dalam masyarakat adat di Minangkabau.
\end{abstract}

Kata Kunci: hermeneutika, songket, simbolik, kebudayaan.

\begin{abstract}
This research is aim to interpret the existence of songket and its relationship to the behavior or culture of indigenous peoples in Minangkabau. Each symbol found on songket can be translated as a way of life in the community in Minangkabau. Therefore, the research method used is a qualitative method, because the object that will examined is Minangkabau songket cloth as a human creation and can be used as a symbol of self-image of the wearer. Obviously it contains elements of values, norms and symbols that are difficult to meet with numbers, statistics and other quantum factors. Values, norms, and symbols may only be met with natural (phenomenological) symptoms, symbolic and cultural interactions or with interactive model analysis. This analysis model has three main analysis component types, namely data reduction, data presentation and conclusion / verification that are intertwined with each other before, during and after data collection. The researcher moves between the four "axes" of the coil and continues until the data / information collected is considered adequate to answer the research problems and draw conclusions. Thus, this research is based on an analysis of the hermeneutic approach, songket woven cloth is a major part of the clothing accessories of traditional stakeholders in the kinship system of the Minangkabau indigenous people, the existence of the songket woven fabric has a special place, besides having a beautiful form sparkling gold thread, Songket woven fabric is also decorated with various decorative motifs that are taken from the forms of plants and animals found around their natural environment. Songket woven cloths as traditional clothing in Minangkabau are in principle an inseparable part of the existence of a traditional stakeholder, especially the Penghulu and Bundo Kanduang. The clothes equipped with songket weaving in the hermeneutic study approach are
\end{abstract}




\section{Gorga Jurnal Seni Rupa \\ Volume 08 Nomor 01 \\ p-ISSN: 2301-5942 | e-ISSN: 2580-2380}

symbols that can be translated into symbolic values that are meaningful to the system of life and example in indigenous peoples in the Minangkabau.

Keywords: hermeneutika, songket, symbolic, cultural.

\section{PENDAHULUAN}

Dalam kehidupan masyarakat Minangkabau terdapat berbagai jenis kriya yang muncul sebagai tuntutan budaya masyarakat tradisi seperti; kriya ukir, tenun/songket, sulam, tembikar/ keramik, kriya anyam dan lain sebagainya.Bentuk kriya ini pada mulanya sederhana namun pada akhirnya disempurnakan sesuai kebutuhan nagari-nagari yang ada di alam budaya Minangkabau. Diantara benda kriya yang dimaksud ada yang dipakai untuk kebutuhan fungsional, dalam pengertian dipakai untuk kebutuhan sehari-hari dan ada pula yang dipakai untuk memenuhi tuntutan upacara adat tradisi Minangkabau.

Salah satu produk kriya yang terkait dengan upacara adat yang dimaksud adalah kain tenun yang berbahan songket. Kain tenun ini umumnya dipakai pada setiap perayaan dan upacara adat masyarakat tradisi Minangkabau seperti upacara adat perkawinan, upacara adat pengangkatan Pangulu, dan upacara lainnya, dapat dipahami bahwa corak pakaian adat atau bangunan adat suatu nagari di Minangkabau bisa berbeda antara satu nagari dengan nagari yang lain. Misalnya pakaian adat tradisi pada daerah Luhak 50 Kota, akan berbeda dengan pakaian adat tradisi di daerah rantau kota Padang, demikian juga bisa berbeda dengan yang di pakai di luhak Agam. Ketiga luhak asal budaya Minangkabau (Agam, 50 Kota, Tanah Datar), luhak-luhak ini sekarang disebut dengan Kabupaten.

Walaupun ada perbedaan corak pakaian suatu nagari, namun tidak setiap nagari di Sumatera Barat memproduksi sendiri bahan pakaian adat itu yang sebagian besar berbahan songket. Diantaranya yang menjadi pusat kriya kain tenun songket ini di Sumatera Barat adalah nagari Silungkang, Pandaisikek (Kabupaten Tanah Datar), Kubang (Kabupaten Lima Puluh Kota). Dari ketiga penghasil Songket itu, hasil produksi kriya songket Silungkang dapat dianggap yang produktif, dengan demikian hasil songket di kawasan ini tersebar ke seluruh daerah Sumatera Barat. Hal ini merupakan salah satu alasan untuk menjadikan songket Silungkang menjadi objek penelitian (lihat gambar 2). Namun alasan yang terpenting adalah bahwa sesuai dengan perjalanan waktu tidak banyak lagi orang yang memahami makna dan nilai yang terkandung dari pakaian adat yang berbahan songket ini yang berasal dari budaya Minangkabau. Banyak literatur mengenai songket seperti songket Palembang, Jambi dan sebagainya, pembahasan mengenai songket Minangkabau boleh dikatakan sangat sedikit. Disamping itu baik secara internasional maupun nasional telah dicanangkan Undang-undang untuk melestarikan "Warisan Budaya Tak-Benda" (intangible cultural heritage), sebab warisan budaya takbenda ini mudah hilang dan tidak diketahui lagi oleh generasi yang akan datang (Sedyawati, 2003:vii-xvii). Berarti bahwa "warisan budaya tak benda" yang tak terlihat dari kriya songket ini penting untuk dilestarikan dan diselidiki.

Ibrahim, dkk. (1986), menjelaskan bahwa pakaian adat tradisional memiliki peranan penting dalam upacaraupacara adat tertentu. Melalui pakaian adat tersebut tergambar pesan-pesan, nilai-nilai budaya yang terkandung di dalamnya, serta berkaitan pula dengan aspek-aspek lain dari kebudayaan seperti ekonomi, sosial, pendidikan, politik dan keagamaan.

Berkenaan dengan pesan nilai-nilai budaya yang ingin disampaikan itu, maka ungkapan makna itu dapat dilihat melalui berbagai sistem penandaan dari ragam cara berpakaian dan ragam hias pakaian adat tradisional tersebut. Menurut Couto (2008) dengan mengutip ilmu bentuk dari Wallsclaeger, C, \& Snyder Cynthia Busic (1992) dan semiotika Sausure dan Pierce, secara teoritik sistem penandaan itu dapat dilihat dari (1) ilmu bentuk, dan, (2) ilmu persepsi atau komunikasi visual, serta (3) sistem tanda, ilmu semiotika (ikon, simbol, indeks), sintaktik dan semantik.

Dari segi ilmu bentuk, maka terdapat perubahan bentuk (transformasi bentuk) dari motif hias ukir bangunan rumah adat ke motif hias songket yang diselidiki oleh Minarsih (1998). Akibatnya sistem makna yang ada pada ukiran rumah adat memiliki kesamaan dengan yang terdapat motif hias tekstil, khususnya songket. Transformasi bentuk adalah akibat perubahan teknik meujudkan motif dengan nama dan makna yang sama tetapi untuk maksud yang berlainan. Transformasi bentuk ini menurut penelitian Couto (1998) juga terdapat dalam ragam kriya ukir rumah adat Minangkabau. Dari segi bahasa visual atau komunikasi visual ada lima cara untuk menyampaikan maksud yaitu secara (1) verbal, (2) nonverbal, gerak- 


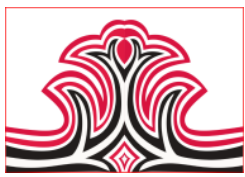

isyarat, (3) gambaran objek, (4) abstraksi gambaran objek, (5) abstrak non-gambaran.
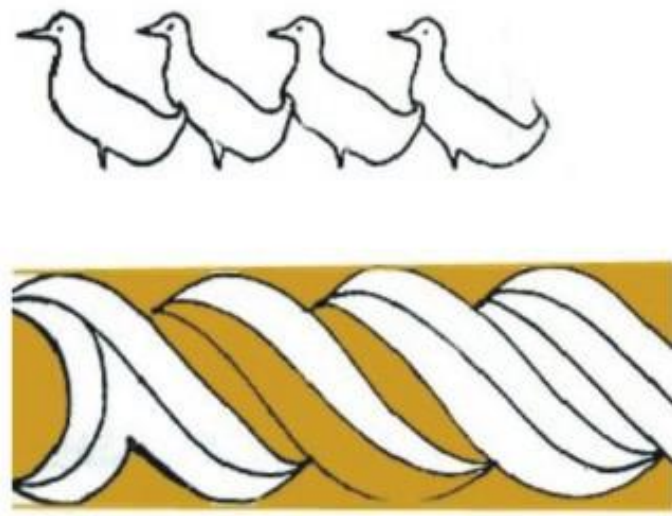

\section{Itiak Pulang Patang}

Gambar 1. Abstraksi Gambaran Objek: Transformasi Bentuk pada Motif Hias Tradisi Minangkabau (Bahas Visual), Nama Motif adalah Bahasa Komunikasi Verbal.

Menurut Couto dalam Sediyawati, (2003), ada dua cara dalam menyampaikan maksud tertentu melalui bahasa visual, pertama adalah melalui elemen (unsur), kedua melalui kumpulan atau susunan elemen (sintaktik) dan atau bahasa bentuk. Dalam hal ini motif hias adalah elemen, cara memakai dan meletakkan elemen dan komposisi elemen adalah sintaktiknya. Keduanya dapat dibaca maknanya (semantik) baik sebagai elemen tunggal (motif hias dan bagian pakaian) maupun sebagai kumpulan elemen (cara berpakaian). Sebab cara berpakaian adalah termasuk kumpulan elemen (sintaktik). Kedua cara ini secara visual dipakai dalam membaca makna pakaian adat tradisional songket Silungkang.

Pembacaan makna (semantik) melalui kumpulan elemen dilakukan berdasarkan aturan-aturan tertentu misalnya (1) kapan suatu jenis pakaian adat dipergunakan, (2) siapa yang harus memakainya, dan (3) bagaimana cara memakainya. Hal ini mengikuti aturan-aturan yang telah disepakati sesuai dengan ketetapan adat di suatu nagari. Hal ini diperkuat oleh Kartiwa (1994) yang menjelaskan bahwa, kain tenun songket merupakan bagian perwujudan budaya masyarakat pemakainya. Antara lain, tidak semua orang dibenarkan memakai busana ini, adanya nilai kesakralan, adanya persyaratan pemakainya, dan nilai simbolis sebagai pakaian kebesaran. Minarsih (1998), juga menjelaskan bahwa yang diperbolehkan memakai kain songket di dalam budaya Minangkabau adalah orang-orang tertentu (terpandang dalam masyarakatnya), yaitu pendukung upacara adat seperti (1) Bundo Kanduang, (2) Datuk dalam berbagai
Gorga Jurnal Seni Rupa

Volume 08 Nomor 0

p-ISSN: 2301-5942 | e-ISSN: 2580-2380

upacara adat dan (3) Penganten dalam upacara adat perkawinan . Betapapun kayanya seseorang dan berkesanggupan memiliki benda itu, namun ia tetap tidak diperkenankan memakai sesuka hati.

Jika pembacaan makna dapat melalui sistem kumpulan elemen (sintaktik) maka pembacaan makna visual (semantik ) yang kedua adalah melalui unsur atau elemen yang terdapat pada pakaian adat (kumpulan elemen), yaitu motif hias. Budiwirman (2003), menjelaskan bahwa, setiap motif hias yang terdapat pada kain tenun songket tradisional terdapat makna-makna tertentu yang telah disepakati bersama oleh masyarakat (konvensi).

Baik makna sintaktik dengan metamorfosisnya, maupun makna elemen dapat dibaca melalui dua cara, yang pertama melalui bahasa visual yang kedua melalui bahasa verbal (misalnya melalui nama setiap motif hias). Seperti yang diterangkan Couto di atas bahwa bahasa visual mudah mengalami transformasi bentuk (ber-metamorfosis), demikian juga sintaktiknya (perubahaan susunan elemen) yang menyebabkan maknanya juga berubah (semantik). Dalam posisi ini maka pembacaan makna akan lebih mudah melalui bahasa verbal. Sebab keduanya (bahasa verbal maupun bahasa visual) memang memiliki hubungan satu dengan yang lainnya yang dibaca melalui ikon (yang menyerupai sesuatu), indeks (yang mengindikasikan sesuatu) dan simbol (kesepakatan makna, atau konvensi). Pembahasan selanjutnya umumnya ditekankan kepada yang terakhir ini yaitu pembacaan makna melalui simbol (lambang). Sebab ini perihal yang diusahakan agar dapat dipertahankan pergenerasi.

Khusus dalam hal lambang, Daryusti (2006), menambahkan, bahwa lambang merupakan unsur yang sangat esensial dalam kehidupan manusia. Bahkan manusia disebut sebagai homosimbolicum, yang artinya sebagai pencipta dan pemberi makna melalui lambang. Lambang adalah "arti sesuatu" berdasarkan persetujuan bersama (konvensi), sebagai sesuatu yang memberikan sifat alamiah dan kualitas yang sama dan dapat mewakili, mengingatkan kembali, atau membayangkan dalam kenyataan atau pikiran.

Jika hal ini dikaitkan dengan perlambangan yang ada pada kain dan cara berpakaian adat minang, maka semua gerak langkah, semua tindakan dan perbuatan harus disesuaikan dengan makna yang disetujui pada pakaian adat itu. Memakai Destar berarti simbol manusia yang telah mencapai taraf pikiran yang 


\section{Gorga Jurnal Seni Rupa \\ Volume 08 Nomor 01 \\ p-ISSN: 2301-5942 | e-ISSN: 2580-2380}

tinggi, berpendidikan, arif dan bijaksana sesuai dengan tempatnya di kepala. Berbagai ragam hias yang terdapat pada Destar ditafsirkan maknanya oleh masyarakat tentang cara berpikir yang baik. Salah satu motif hias misalnya, Pucuk Rebung, dalam falsafah adat rebung ini adalah perlambang manusia terpakai, yang tertera dalam kata mamangan: " muda berguna, tua terpakai", menjadi contoh tauladan bagi kaumnya.

Kemudian kain tenun songket yang dijadikan pakaian seperti Baju, diistilahkan pandindiang miang, ialah suatu kain yang diperuntukkan bagi tirai yang melekat pada dinding.

Makna dari kain pandindiang miang bagi masyarakat Nagari Silungkang ialah agar berjalan dan hidup penuh perasaan dengan bertitik tolak pada alam takambang dijadikan guru (alam terhampar dijadikan guru). Baju yang melekat dibadan tidak hanya dijadikan pembalut tubuh saja, melainkan diikuti oleh langan besar dan longgar. Lengan yang besar diibaratkan sebagai pengipas jika panas agar jadi sejuk baik untuk diri sendiri maupun untuk anak Kemenakan, potongan yang besar mengibaratkan sipemakai berjiwa besar, beralam lapang, bersifat sabar. Perwujudan baju ini menggambarkan sifat yang harus dimiliki serta keharusan oleh seorang pemimpin untuk ditaati ditengah kampung.

Didasarkan pada fungsi dan makna filosofis baju menunjukkan sipemakai harus memiliki hati lapang sebagai inti dalam menyelesaikan segala permasalahan yang tedapat dalam lingkup komunitas kaumnya, permasalahan tersebut dapat diselesaikan manakala cukup syarat melalui kata-kata bijak dalam satu perundingan, (Budiwirman, 2016).

Umumnya pengetahuan tentang pemakaian dan pembuatan pakaian adat beserta kelengkapannya, diajarkan secara lisan atau dengan cara menirukan dan berlangsung secara turun-temurun (Ibrahim, dkk. (1986). Pengetahuan itu hanya dicatat dalam ingatan dan berulangkali dipraktekkan setiap dibutuhkan oleh keluarga yang akan mengikuti upacara-upacara bersangkutan. Oleh karena semuanya tidak tertulis dan hanya ada dalam ingatan saja. Maka sebagaimana diuraikan di atas, mendorong dilakukannya penelitian dan pengkajian lebih dalam terhadap "Makna Pendidikan pada Kriya Songket Silungkang Sumatera Barat".

\section{METODE PENELITIAN}

Untuk melakukan kajian tentang Hermeneutika songket sebagai pakaian adat dalam perspektif budaya Minangkabau pada kain tenun Songket dengan unsur-unsur pokok yang harus ditemukan maka digunakan metodologi penelitian Etnografi,. Spradley (1997), menjelaskan bahwa metode Etnografi adalah merupakan metode yang digunakan untuk meneliti masyarakat dan makna terhadap objek yang diteliti. Metode etnografi menyiratkan suatu cara kerja (pendataan, analisis, dan penyajian) yang bersifat menyeluruh atau holistik.

Adapun jenis penelitian yang digunakan terkait dengan metode etnografi adalah penelitian kualitatif. Maksudnya, temuan-temuan dilapangan akan diolah secara deskripsi kualitatif. Dengan kata lain prosedur penelitian yang menghasilkan data deskriptif berupa kata-kata tertulis atau lisan dari orang-orang dan perilaku yang dapat diamati (Bogdan,1975).

Objek penelitian ini adalah kain tenun songket sebagai ciptaan manusia. Jelaslah akan mengandung unsur-unsur nilai, norma dan lambang yang sulit dipertemukan dengan faktor angka, statistik dan kuantum lainnya. Nilai, norma dan lambang hanya mungkin dipertemukan dengan gejala-gejala alami (fenomenologis), interaksi simbolik dan budaya (Moleong, 1989).

Oleh sebab itu, interaksi simbolik dan budaya tersebut adalah tiga serangkai, modus yang bila dihadapkan kepada budaya tradisional di Minangkabau, maka akan kentara sekali sentuhan-sentuhannya terhadap beberapa aspek budayanya.

Interaksi simbol dari pakaian adat tersebut dapat dilihat pada aspek budaya fisiknya. Diantara wujud budaya fisik yang paling menonjol interaksinya disamping bahasa visual, juga terdapat dalam bahasa verbal yaitu "petatah-petitih". Petatah-petitih mengandung lambang diskursif. Pakaian adalah bahasa visual yang mengandung lambang presentational. Artinya petatah-petitih sebagai suatu ungkapan pikiran disampaikan secara berkias sekaligus merupakan lambang diskursif mengandung makna untuk dimengerti. Pakaian adat sebagai wujud budaya fisik (tangible culture) mengandung pesan untuk dipakai dan diresapi. Yang berarti dapat dimengerti makna-makna yang ada di dalamnya.

Dengan penggunaan metode ini, maka dapat ditemukan data yang bersifat proses kerja, deskripsi yang luas dan mendalam, perasaan, norma, keyakinan, 


\section{Gorga Jurnal Seni Rupa \\ Volume 08 Nomor 01 \\ p-ISSN: 2301-5942 | e-ISSN: 2580-2380}

sikap mental, etos kerja, dan budaya yang dianut seseorang maupun sekelompoknya. Dengan demikian maka akan dapat diperoleh data yang lebih luas, pasti, sehingga memiliki validitas yang tinggi dan mendalam.

\section{HASIL DAN PEMBAHASAN}

\section{Hasil}

Kain tenun songket merupakan bagian dari perangkat pakaian adat di Minangkabau, sebagaimana yang telah diuraikan pada bagian terdahulu, bahwa pakaian adat terdiri dari; pakaian Pangulu, Manti, Dubalang, dan Bundo Kanduang. Keberadaan kain tenun songket dengan ragam hias yang terdapat pada kain tenun tersebut merupakan lambang yang memiliki makna tertentu yang erat kaitannya dengan fungsi dari masing-masing pemangku adat yang menggunakan pakaian tersebut. Marianto (2006) mengatakan, bahwa hermeneutika dapat diartikan sebagai seni atau keterampilan menafsirkan, menilai atau memaknai dari suatu teks dalam suatu konteks tertentu, ia dapat diartikan sebagai metode untuk menilai makna dalam ekspresi kultural apa saja. Misalnya, upaya untuk mengungkap nilai-nilai yang terkandung dalam makna lambang yang terdapat pada suatu budaya masyarakat, dapat juga dikatakan sebagai suatu praktik hermeneutika.

Analisis data dilakukan dengan menggunakan sudut pandang filsafat hermeneutika yaitu melakukan interpretasi terhadap data terkait dengan pandangan masyarakat terhadap kain tenun songket Minangkabau. Interpretasi dilakukan dengan mendiskusikan antara kain tenun songket sebagai sebuah produk kerajinan masyarakat dengan kain tenun songket sebagai bagian dari pakaian adat masyarakat Minangkabau.

Kain tenun songket merupakan produk kerajinan milik masyarakat Minangkabau, merupakan produk kerajinan tenun yang diproduksi secara manual menggunakan alat tenun bukan mesin (ATBM). Bahan yang digunakan untuk memproduksi kain songket merupakan bahan khusus, seperti kain sutra, kain katun dengan mutu pilihan, dan benang emas pilihan. Ditinjau dari sudut pandang proses pengerjaan, untuk menghasilkan sehelai kain tenun songket, dibutuhkan waktu waktu lebih kurang satu Minggu. Sedangkan dari sudut pandang pengerjaan, untuk melakukan pekerjaan menenun kain songket, diperlukan satu keterampilan dengan penagalaman yang tinggi. Oleh karena itu sebuah kain tenun songket dipandang dari sudut penggunaan bahan dan waktu yang dibutuhkan untuk produksi dan keterampilan yang dibutuhkan, jelaslah bahwa kain tenun songket memiliki nilai tersendiri dibandingkan dengan kain atau tekstil biasa. Keistimewaan kain tenun songket menjadi lebih kongkrit ketika harga jual sehelai kain tenun songket dibandingkan dengan sehelai kain atau tekstil biasa, bahwa harga kain tenun songket lebih mahal dibandingkan dengan kain atau tekstil biasa. Berdasarkan uraian di atas dapat disimpulkan bahwa keberadaan kain tenun songket sebagai sebuah produk kerajinan tangan memiliki nilai intrinsik yang istimewa dibandingkan produk kain biasa.

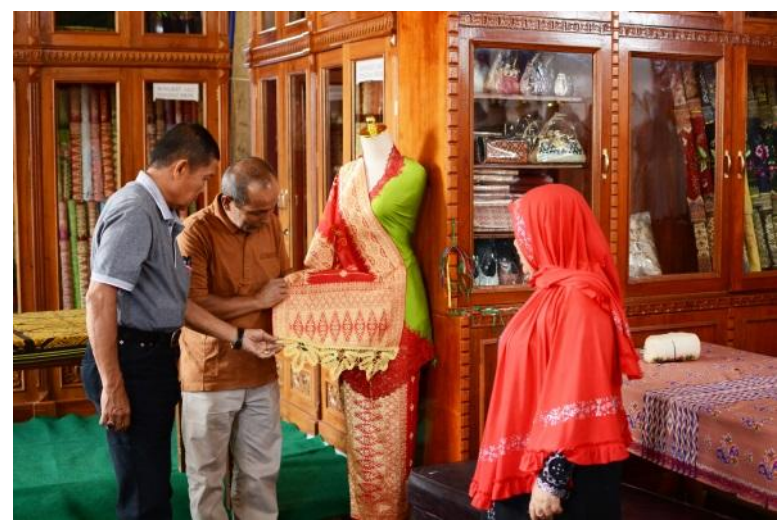

Gambar 2. Kain Tenun Songket Sentra Pak Datuk Jenis Songket-Sulam

(Dokumentasi: Syafwandi, 2018)

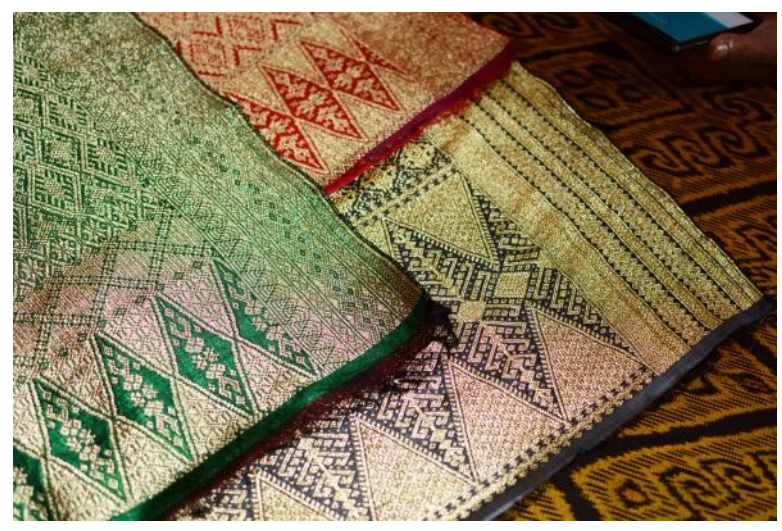

Gambar 3. Kain Tenun Songket Sentra Pak Datuk Kualitas Sutra (Dokumentasi: Budiwirman, 2018) 


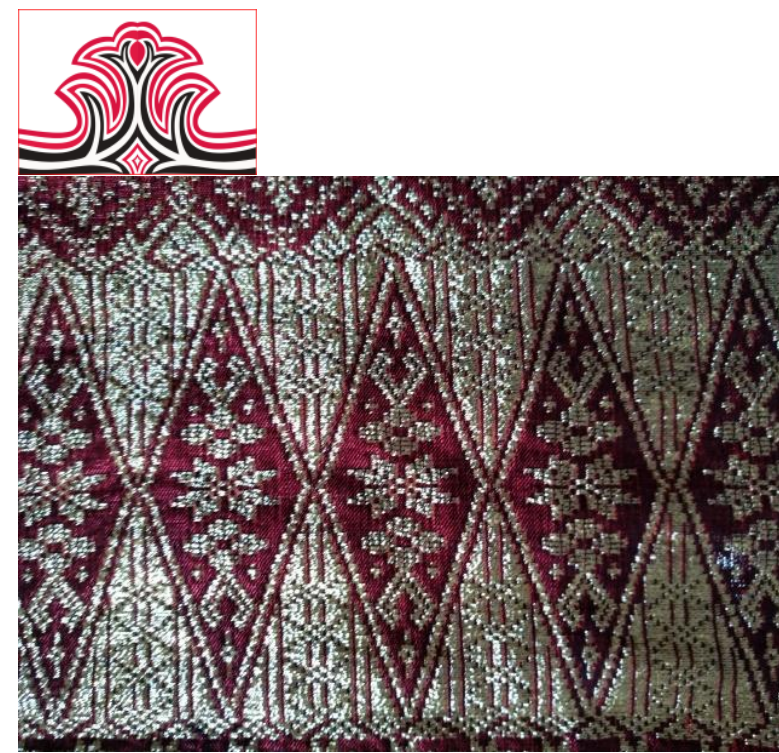

Gambar 4. Kain Tenun Songket Koleksi Ibu Zubaidah (Dokumentasi: Syafwandi, 2018)

\section{1).Kain Tenun Songket sebagai Pakaian Adat}

Data lapangan menyatakan bahwa kain tenun songket ternyata digunakan sebagai bahan untuk membuat pakaian adat masyarakat Minangkabau. Menurut (..........) adalah kebiasann yang memiliki nilai-nilai sesuai dengan pandangan hidup satu kelompok masyarakat. Begitu pula dengan masyarakat Minangkabau, bahwa masyarakat adat Minangkabau memiliki struktur kelembagaan yang mengatur sistem kekerabatan berlaku dalam masyarakat. Begitu pula dengan konsep berpakaian, terutama pakaian para pemangku kebijakan seperti pangulu dan perangkatnya.
Gorga Jurnal Seni Rupa

Volume 08 Nomor 0

p-ISSN: 2301-5942 | e-ISSN: 2580-2380

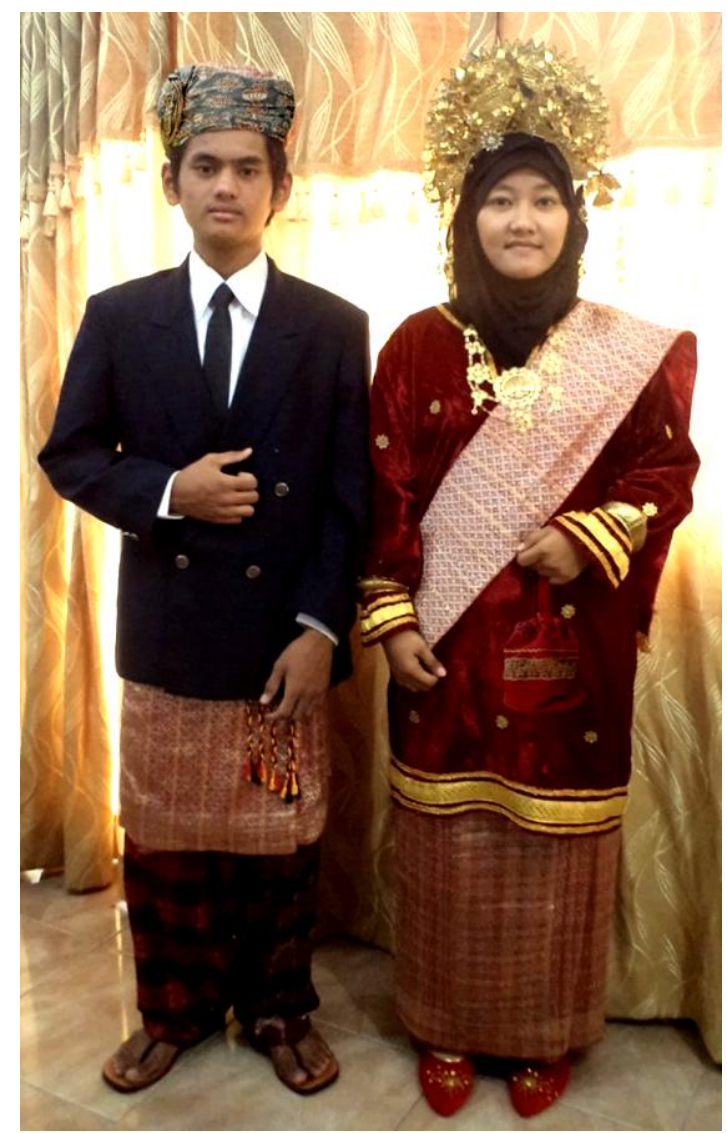

Gambar 5. Busana Pengantin Masyarakat Kurai Bukittinggi (Dokumentasi: Rona Rahayu Yunus, 2014)

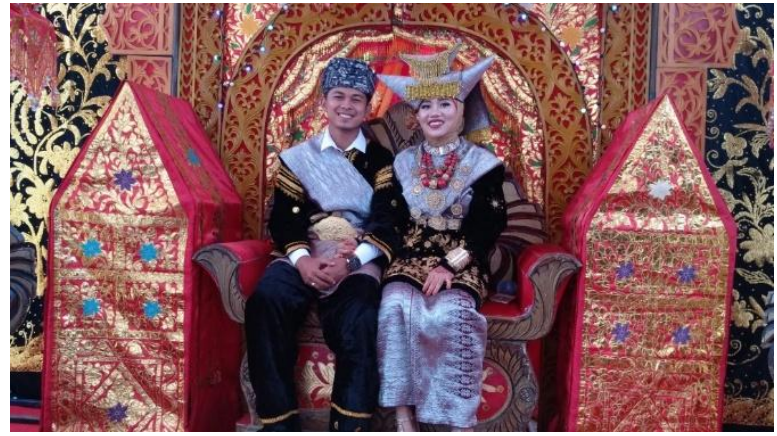

Gambar 6. Sepasang Pengantin dengan Pakaian Adat Nagari Tanjung Bonai Kecamatan Lintau Buo Utara

(Dokumentasi: Syafwandi, 2018)

Berdasarkan fakta berkaitan dengan penggunaan kain tenun songket dalam masyarakat adat Minangkabau dapat ditarik sebuah kesimpulan, bahwa kain tenun songket merupakan kain kebesaran masyarakat Minangkabau. Pakaian kebesaran tidak hanya bagi perangkat adat, akan tetapi bagi segenap anggota masyarakat Minangkabau. 


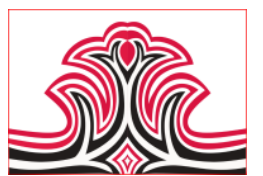

2).Kain Tenun Songket dan Masyarakat Adat Minangkabau

Kain tenun songket pada dasarnya juga digunakan oleh kalangan masyarakat biasa di Minangkabau. Terutama untuk menghadiri undangan, seperti upacara pernikahan, upacara turun mandi, dan upacara penyambutan tamu pemerintah. Para tamu undangan baik kaum laki-laki maupun kaum perempuan datang dengan memakai pakaian terbuat dari kain tenun songket. Namun demikian tidak semua para undangan datang memakai pakaian kain tenun songket. Ada beberapa kemungkinan alasan kenapa tamu tidak menggunakan pakaian kain songket. Kemungkinan pertama adalah orang yang diundang hanya tamu biasa dalam upacara tersebut, sehingga tamu itu tidak terlalu penting untuk memakai pakaian songket. Kemungkinan kedua adalah tamu yang diundang memang tidak memiliki pakaian yang terbuat dari kain tenun songket. Hal ini sangat dimungkinkan karena tidak ada aturan yang mengharuskan seseorang tamu undangan harus datang menggunakan pakaian tenun songket. Selain itu, mengingat harga sehelai kain tenun songket sangat mahal, maka belum semua orang mampu membeli kain tenun songket. Namun demikian, berdasarkan data yang diperoleh dilapangan, ada individu yang selalu menggunakan pakaian terbuat dari kain tenun songket dalam menhadiri berbagai undangan upacara. Hal ini dilakukan karena pertimbangan pribadi dan prestise yang diperoleh melalui kain tenun songket. Bahwa individu yang tampil dengan pakaian terbuat dari kain songket dapat memberikan citra tentang keelokan tampilan, sekaligus memperlihatkan status sosial bagi pemakainya.

Pada upacara penyambutan tamu pemerintah mulai dari penyambutan pejabat kecamatan, kabupaten kota, maupun pejabat kenegaraan, para istri pejabat yang menanti biasanya juga mengenakan pakaian terbuat dari kain tenun songket. Pada upacara penyambutan tamu pemerintah biasanya juga dilakukan dengan sebuah pertunjukan dengan menyuguhkan tari khas daerah Minangkabau, yaitu tari pasambahan. Para penari juga menggunakan pakaian yang terbuat dari kain tenun songket.
Gorga Jurnal Seni Rupa

Volume 08 Nomor 0

p-ISSN: 2301-5942 | e-ISSN: 2580-2380

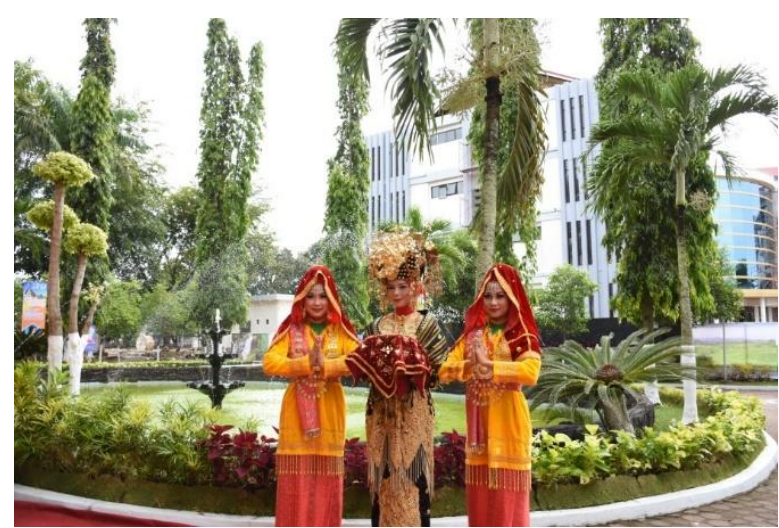

Gambar 7. Para Pembawa Carano pada Tari Pasambahan Jurusan Sendratasik Universitas Negeri Padang (UNP) Padang

(Dokumentasi: Syailendra, 2018)

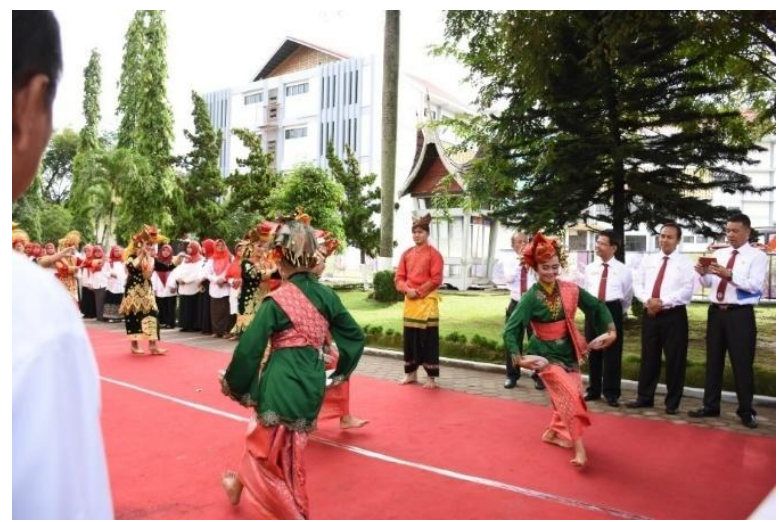

Gambar 8. Pasambahan oleh Mahasiswa Jurusan Sendratasik UNP Padang (Dokumentasi: Syailendra, 2018)

\section{Pembahasan}

Temuan dilapangan mengatakan bahwa kain tenun songket dalam tradisi masyarakat Minangkabau merupakan perangkat pakaian adat, tenun songket dipakai oleh Pangulu, Bundo Kanduang, dan segenap anggota masyarakat di Minangkabau. Kain tenun songket dipakai oleh semua perangkat pemangku adat pada saat melangsungkan sebuah upacara adat. Pemangku adat dalam konteks kain tenun songket adalah segenap anggota masyarakat yang memiliki kepentingan dalam menggunakan kain tenun songket pada saat upacara adat berlangsung. Ketika berlangsung sebuah upacara adat, maka pada saat bersamaan segenap anggota masyarakat yang terkait dengan upacara tersebut dapat menggunakan kain tenun songket sebagai pakaian adat. Pakaian yang terbuat dari kain tenun songket dipandang sebagai pakaian kebesaran setiap pemangku adat. Bagi masyarakat biasa, kain tenun songket adalah pakaian kebesarannya sebagai anggota masyarakat. Sedangkan bagi perangkat adat seperti Pangulu, Monti, Bilal, Dubalang, dan Bundo Kanduang memiliki pula pakaian kebesaran sesuai dengan jabatan yang 


\author{
Gorga Jurnal Seni Rupa \\ Volume 08 Nomor 01 \\ p-ISSN: 2301-5942 | e-ISSN: 2580-2380
}

diembanya. Pembeda antara kain tenun songket yang digunakan oleh masyarakat biasa dengan pakaian yang digunakan oleh perangkat Pangulu terletak pada bentuk struktur pakaian. Perangkat pakaian Pangulu memiliki bentuk dan struktur berkaitan dengan tugasnya masing-masing (Ilhaq, M. 2018). Setiap bagian dari pakaian pangulu terdapat makna berisi pesan tentang nilai-nilai luhur yang dapat dijadikan panduan atau acuan dalam menjalankan tugas sebagai pemimpin kaum (Juita, N: 2017). Bagian pakaian kebesaran Pangulu yang menggunakan kain tenun songket adalah salempang, sisampiang, dan cawek. Seorang pemimpin dalam pandangan orang Minang adalah sebagai pengayom dan pelindung masyarakat (Kosasih, A: 2013).

Setiap bagian dari pakaian pangulu terdapat makna berisi pesan tentang nilai-nilai luhur yang dapat dijadikan panduan atau acuan dalam menjalankan tugas sebagai pemimpin kaum (Juita, N: 2017). Bagian pakaian kebesaran Pangulu yang menggunakan kain tenun songket adalah salempang, sisampiang, dan cawek. Seorang pemimpin dalam pandangan orang Minang adalah sebagai pengayom dan pelindung masyarakat (Kosasih, A: 2013). Pakaian kebesaran yang dimiliki oleh pangulu merupakan cerminan tugas atau amanah yang harus dipegang teguh oleh seorang pangulu. Begitu pula dengan Bundo Kanduang sebagai bagian dari perangkat pangulu, Bundo Kanduang sebagai pimpinan sosial (Kosasih, A: 2013). Bundo Kanduang sebagai seorang pemimpin berperan dalam mengontrol berbagai persoalan yang terjadi di masyarakat. Bundo Kanduang merupakan ibu yang memiliki hak atas segala persoalan yang terjadi di kalangan anggota masyarakat. Bundo Kandung adalah pengayom, pengarah terhadap semua anggota masyarakat. Oleh karena itu pakaian Bundo Kanduang juga sangat berbeda dengan pakaian adat masyarakat biasa yang dipimpinya.

Bagi seorang pangulu, pemimpin kaum dalam sebuah wilayah adat, menggunakan kain tenun songket sebagai pakaian kebesaranya. Pakaian tersebut merupakan simbol yang melambangkan kepemimpinan yang adil dan bijaksana sesuai dengan hukum adat Minangkabau. Sedangkan bagi masyarakat biasa keberadaan kain tenun songket dapat menjadi simbol yang melambangkan penghargaan terhadap adat istiadat yang harus dijunjung tinggi. Selain itu dalam kehidupan sehari-hari bagi masyarakat Minangkabau, memiliki pakaian yang terbuat dari kain tenun songket merupakan sebuah kebanggaan terhadap karya tradisional masyarakat petenun Minangkabau. Keberadaan kain tenun songket Minangkabau juga memberikan sebuah sinyal kesetaraan dengan masyarakat adat lainnya yang juga memiliki sentra kain tenun songket.

\section{KESIMPULAN DAN SARAN}

Masyarakat Minangkabau sebagai elemen pendukung keberlangsungan adat Minangkabau memandang kain tenun songket sebagai sebuah produk budaya yang memiliki nilai estetika, dan menjadi simbol yang melambangkan kemapanan sistem matrilini pada masyarakat Minangkabau. Kain tenun songket adalah jati diri masyarakat Minangkabau, hal ini dijelaskan oleh keberadaan ragam hias Minangkabau yang menjadi elemen estetik yang memiliki nilai filosofi berkaitan dengan sistem kekerabatan masyarakat Minangkabau. Kain tenun songket dijadikan sebagai sebuah properti, yaitu sebuah kekayaan yang memiliki nilai tersendiri dalam kehidupan masyarakat Minangkabau. Kain tenun songket dipandang sebagai aset yang dapat diwariskan dari generasi ke generasi, karena pada dasarnya kain tenun songket adalah simbol tentang keberadaan, sebuah entitas yang membuat seseorang menjadi ada dan dikenal. Kain tenun songket bukanlah pakaian sehari-hari, pakaian songket hanya dipakai pada saat-saat tertentu saja, terutama pada even yang sangat berharga.

\section{DAFTAR RUJUKAN}

Bogdan, Robert and Steven J. Taylor. (1975). Introduction to Qualitative Research Methods (The Search For Meaning), New York: John Wiley \& Son.

Yunus, R. R., Efi, A., \& Yuliarma, Y. (2014). Studi Tentang Busana Pengantin Tradisional Kurai Bukittinggi. E-Journal Home Economic And Tourism, 6(2).

Efriani, R., Nazar, E., \& Nelmira, W. (2018). Aturan

Pakaian Untuk Menghadiri Baralek Perkawinan Bagi Wanita Di Kenagarian Vii Koto Talago Kecamatan Guguak Kabupaten Lima Puluh Kota. E-Journal Home Economic And Tourism, 15(2).

Zubaidah. (2009). Implementasi Makna Simbol Pakaian Adat Wanita Terhadap Sistem Kemasyarakatan Minangkabau;Kajian Rupa pada Struktur, Warna, Motif Hias Pakaian Adat Kaum Perempuan Minangkabau Sumatera Barat.Dp2mSurat Perjanjian No. 1444/H35/Ku/Dipa/2009 Tanggal 16 April 2009 Direktorat Jenderal Pendidikan Tinggi Departemen Pendidikan Nasional. 


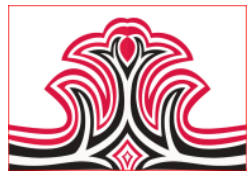

Budiwirman. (2003). Kain Tenun Songket

Minangkabau, (Kajian Fungsi Songket dalam Perubahan Sosial-Budaya Masyarakat Minangkabau (Thesis S.2), Padang: Pascasarjana Universitas Negeri Padang. . (2016). Metaphor of Silungkang

Ornament Songket, (Journal of Scientific

Research andStudies. Vol 3(10). ISSN 2375 8791)

Couto, Nasbahry. (1998). Makna dan Unsur-Unsur Visual pada Bangunan Tradisional Minangkabau: Suatu Kajian Semiotik, ( Studi

Kasus: Bangunan Rumah gadang di Sehiliran "Batang Bengkawas" Kabupaten

Tanah Datar Sumatera Barat) . (2008). Budaya Visual pada Seni Tradisi Minangkabau, Padang: UNP.Press. (2010). Psikologi Persepsi dalam

Kawasan Desain Komunikasi Visual, Padang: UNP Press.

Daryusti. (2006). Hegemoni Pangulu dalam Perspektif Budaya,Jakarta: Penerbit Pustaka.

Ibrahim, Anwar,dkk. (1986). Pakaian Adat Tradisional daerah Sumatera Barat, Padang: Departemen Pendidikan dan Kebudayaan, Direktorat Jenderal Kebudayaan, Direktorat Sejarah dan Nilai Tradisional, Proyek Inventarisasi DokumenDaerah.

Ismael, Sudirman. (2007). Arsitektur Tradisional Minangkabau: Nilai-nilai Budaya dalam Arsitektur Rumah Adat, Padang: Bung Hatta University Press.

Marianto, M Dwi. (2006). Quantum Seni, Semarang: Dahara Prize

Minarsih. (1998). Korelasi antara Motif Hias Songket dengan Ukiran Kayu di Provinsi Sumatera Barat, (Tesis), Bandung: I T B.

Moleong, Lexy J. (1989). Metodologi Penelitian Kualitatif, Bandung: Penerbit Remaja Karya CV.

Riza Mutia, dkk. (1997). Pakaian Pangulu Minangkabau, Padang: Bahagian Proyek Permuseuman Sumatera Barat.

Sedyawati, Edi., ed al. (2003). Warisan Budaya Takbenda, Jakarta, Depok: Pusat Penelitian Kemasyarakatan dan Budaya Lembaga Penelitian Universitas Indonesia.

Spradley P.James. (1997). Metode Etnografi, Yogyakarta: PT.Tiara Wacana.
Gorga Jurnal Seni Rupa

Volume 08 Nomor 01

p-ISSN: 2301-5942 | e-ISSN: 2580-2380

Wallsclaeger, C, \& Snyder Cynthia Busic; (1992). Basic Visual Concepts and Principles: for artists, Architects, and Designers.The Ohio State University:WBC 